\title{
Transition from Care to Adulthood: A Systematic Review of Intervention Programs
}

\author{
Luciana Cassarino-Perez*, 1 \\ Orcid.org/0000-0003-4075-2832 \\ Vitória Ermel Córdova ${ }^{1}$ \\ Orcid.org/0000-0003-1629-339X \\ Carme Montserrat ${ }^{2}$ \\ Orcid.org/0000-0001-5062-1903 \\ Jorge Castellà Sarriera ${ }^{1}$ \\ Orcid.org/0000-0001-8297-4957
}

${ }^{1}$ Universidade Federal do Rio Grande do Sul, Porto Alegre, RS, Brasil

${ }^{2}$ Universitat de Girona, Catalunha, Espanha

\begin{abstract}
The objective of this study was to map the scientific production of the last decade on intervention programs to favor the emancipation of youth leaving the protection system after turning 18 years old. Twenty articles were selected through a systematic review of literature. These articles were indexed in the following databases: Scientific Electronic Library Online (SciELO), Literatura LatinoAmericana e do Caribe em Ciências da Saúde (LILACS), PubMed, PsycINFO, Pro Quest Psychology Journals and Web of Science. The majority of the articles were written in North America, using either longitudinal or transversal quantitative design. The studies evaluated the interventions using three types of evaluation design: process (15), effect (15) and impact (2). The programs differed in type (housing, short-term and or long-term); content (independent life skills, education and work); and method (different degrees of participation). Besides exploring the strengths and weaknesses of each intervention program, this article discusses the relevance of the evaluation processes to scientific advance in this field. As a conclusion, it is argued that to favor the transition process the intervention should have the following characteristics: in long-term basis; combine independent life skills with emotional, social and community support; to consider participants individual and cultural differences as well as their capability of making decisions.
\end{abstract}

Keywords: Residential care, foster care, adolescence, intervention.

* Mailing address: Universidade Federal do Rio Grande do Sul, Grupo de Pesquisa em Psicologia Comunitária, Rua Ramiro Barcelos, 2600, sala 122, Porto Alegre, RS, Brazil 90035-003. Phone: (51) 3308-5239. E-mail: lucicaspe@gmail.com 


\section{Transição entre o Acolhimento e a Vida Adulta: Uma Revisão Sistemática sobre Intervenções}

\section{Resumo}

O objetivo deste artigo foi mapear a produção científica dos últimos dez anos no que se refere a programas de intervenção para favorecer o processo de emancipação de adolescentes que deixam o sistema de proteção por motivo de maioridade. Através de uma revisão sistemática da literatura, foram selecionados 20 artigos indexados nas bases de dados Scientific Electronic Library Online (SciELO), Literatura Latino-Americana e do Caribe em Ciências da Saúde (LILACS), PubMed, PsycINFO, Pro Quest Psychology Journals e Web of Science. Prevaleceram os estudos norte-americanos, de delineamento quantitativo tanto longitudinal quanto transversal. Os estudos avaliaram os programas de intervenção através de análises do processo (15), efeito (15) e impacto (2). Os programas variaram em formato (moradia, pontuais e contínuos); conteúdo oferecido (habilidades para a vida independente, educação, trabalho) e método utilizado (participativo ou passivo). Além de analisar as fortalezas e fraquezas de cada programa, o artigo discute a importância dos processos avaliativos para a prática e avanço científico. Conclui-se que para favorecer o processo de transição os programas devem ter duração continuada; aliar treinamento em habilidades para a vida independente com acompanhamento sócio emocional e inserção comunitária; respeitar as diferenças individuais dos participantes e considerá-los como agentes ativos na tomada de decisões.

Palavras-chave: Acolhimento institucional, acolhimento familiar, adolescentes, intervenção.

\section{Transición entre el Acogimiento y la Vida Adulta: Una Revisión Sistemática sobre Programas de Intervención}

\section{Resumen}

El objetivo de este artículo fue revisar la producción científica de los últimos diez años sobre programas de intervención para favorecer la emancipación de adolescentes que dejan el sistema de protección por mayoridad. A través de una revisión sistemática, fueron seleccionados 20 artículos en las bases de datos Scientific Electronic Library Online (SciELO), Literatura Latino-Americana y del Caribe en Ciencias de la Salud (LILACS), PubMed, PsycINFO, Pro Quest Psychology Journals y Web of Science. La mayoría de los estudios fueron realizados en Norteamérica con diseño cuantitativo longitudinal o transversal. Los estudios evaluaron programas a través de análisis del proceso (15), efecto (15) e impacto (2). Los programas eran distintos en su forma (vivienda, de corto o largo plazo); contenido (habilidades para la vida independiente, educación, trabajo) y método (con diferentes niveles de participación). Además de analizar fortalezas y debilidades de cada programa, se discute la importancia de la evaluación para la práctica profesional y avance científico. Se concluye que, para favorecer el proceso de transición, los programas deben tener como características: duración continuada; combinar entrenamiento en habilidades de vida independiente con apoyo socioemocional e inserción comunitaria; considerar las diferencias individuales y culturales de los participantes y reconocerlos como capaces de tomar sus decisiones.

Palabras clave: Acogimiento residencial, acogimiento familiar, adolescencia, intervención.

The emancipation of former foster youth and individuals with a history of group home placement has received increasing attention in the scientific literature, and has been the subject of a considerable number of publications in the past ten years. Though most articles on the subject are in international journals rather than Brazilian publications, there has been significant national interest in this area of study, as evidenced by several recent articles (Martinez \& 
Soares-Silva, 2008; Rosa, Nascimento, Matos, $\&$ Santos, 2012), theses and dissertations (Costa, 2012; Medrado, 2010; Moreira, 2013; Romanelli, 2013).

Though foster families are mentioned in Brazilian law, foster care accounts for only $5 \%$ of placements among children and adolescents in state custody, with most individuals housed in institutional shelters or group homes $(\mathrm{Na}-$ tional Council of the Public Ministry [CNMP], 2013). As they approach maturity, adolescents who live in these institutions are required to take responsibility for their own lives, whether or not they are ready for the transition. A recent survey performed by the CNMP found that 1,141 adolescents aged out of foster care between March 2012 and March 2013. This figure is highest in south and southeastern Brazil, with the majority of cases occurring in the states of São Paulo and Rio Grande do Sul.

According to the literature, individuals who age out of foster care are at a disadvantage relative to youth raised by their families (Hudson \& Nandy, 2012; Mersky \& Janczewski, 2013). Institutional care is associated with several developmental risk factors, such as neglect, abandonment, maltreatment, sexual abuse and poverty (Siqueira \& Dell'Aglio, 2006). In addition to these sources of risk, foster youth must also face a sudden transition to independent living as they age out of government or state care (Federación de Entidades con Proyectos y Pisos Asistidos [FEPA], 2014; Montserrat, Casas, \& Sisteró, 2015).

These circumstances increase the vulnerability of former foster youth, placing them at higher risk of unemployment (Stewart, Kum, Barth, \& Duncan, 2014), illicit substance use (Hudson \& Nandy, 2012), health problems (Rahamim \& Mendes, 2016), early childbearing (Oshima, Narendorf, \& McMillen, 2013), conflict with the law (Mersky \& Janczewski, 2013) and homelessness (Dworsky, Napolitano, \& Courtney, 2013). However, studies have also investigated resilience in these individuals, discussing their ability to overcome therisk factors to which they are exposed. Studies conducted in Spain and the United States have identified varying levels of adaptation to the transition from foster care to adulthood, classifying former foster youth from least adapted to most resilient (del Valle, Bravo, Alvarez, \& Fernanz, 2008; Yates \& Grey, 2012). These studies have found that many adolescents overcome adversity, but note that resilience may be limited to only some domains of functioning, highlighting the need for more global interventions (cognitive, social, emotional, physical, etc.) in this population.

The emancipation of foster alumni is a unique and personal journey, influenced by the individual's ties to their birth family and shelter institution, as well as their personality traits. The influence of context on emancipation underscores the need for specific public policies and programs to facilitate this dynamic and complex process when it occurs outside one's birth family. When action plans that consider the individual characteristics of youth are put in place, the transition process is likely to be successful (FEPA, 2014).

The past few decades have seen growing efforts from first, second and third sector institutions and organizations in several countries to facilitate the transition of foster youth into adulthood both before and after they leave the protection system. These interventions include the Foster Care Independence Act (P.L. 106-169), in the United States; the Area de Apoyo a los Jóvenes Tutelados y Ex-Tutelados (ASJTET), in Catalunya, Spain; the Grupo Nós at the Fazendo História Institute, in Brazil; the Punt de Referência program, in Spain; the Strive program, set up by the Young Women's Christian Association (YWCA) in Canada; and the Corporate Parenting program, in the United Kingdom. The aim of these initiatives is to facilitate the transition from foster care to adulthood. As such, they address issues such as living arrangements, daily life activities, education and preparation for work, interpersonal relationships, community participation and life projects.

Interventions consist of activities planned to effect a specific change and solve a particular problem (European Union, 2014). Psychosocial interventions targeting issues such as the transition from foster care to adult life are especially 
complex, as they must extend to several domains (e.g., personal, relational, community) in order to achieve the desired outcomes (Nelson \& Prilleltensky, 2005). Therefore, psychosocial interventions must be carefully planned and precisely executed according to specific guidelines. The development of an intervention program is usually conducted according to the following steps: needs and context assessment; program design; viability assessment; implementation; dissemination and evaluation of the intervention (Blanco \& Valera, 2007; European Union, 2014).

Both evaluation and dissemination aim to investigate the extent to which the program contributed to the desired change, but also to share the results with the community and provide research returns. The present systematic review focused on studies which sought to address the actual needs of a particular group of people. The overall goal was to describe the scientific literature of the past ten years pertaining to interventions aimed at facilitating the emancipation of agedout foster youth. The main findings of these studies were summarized, to provide the basis for future research, interventions and public policies directed at this population.

\section{Method}

This systematic review was conducted according to PRISMA (Preferred Reporting Items for Systematic Reviews and MetaAnalyses) guidelines, which separates the process into four stages: Identification, Selection, Eligibility and Inclusion (Liberati et al., 2009). The identification stage took place between September and December 2016, at which point an electronic search was conducted in the following databases: Scientific Electronic Library Online (SciELO), Literatura LatinoAmericana e do Caribe em Ciências da Saúde (LILACS), PubMed, PsycINFO, ProQuest Psychology Journals and Web of Science. The keywords used in the search consisted of the following: "Foster care"; "foster youth"; "young adult"; "young people"; "transition from"; "aging out"; "leaving"; "independent living" and "autonomy". Most of these terms are not indexed as Health Science Descriptors (Descritores em Ciências da Saúde; DeCS). As such, the identification of the most adequate terms for the search involved a review of the keywords used in existing articles on the topic, and consultation with other researchers in the area. Keyword combinations were generated using an " $a+b$ + c" format, where: (a) context (foster care; residential care; out of home care; care system); (b) situation (transition from; aging out; leaving; independent living; autonomy); and (c) sample (foster youth; young adult; young people). Each combination was used in a separate search until all possible combinations were exhausted. No filters were used in the search. Searches were also conducted using keywords in Spanish and Portuguese. In Spanish, the general term "jovenes ex-tutelados" was used, while in Portuguese, the following keywords were combined: "egressos" or "jovens", with "acolhimento institucional" or "abrigo" or "sistema de proteção". A total of 2163 articles were retrieved in the search.

The selection stage involved screening for duplicates in the findings. This procedure identified a total of 1585 unique articles, whose abstracts were then screened for the following inclusion criteria: (1) empirical studies; (2) published in the past 10 years; (3) in English, Portuguese or Spanish; (4) sample consisting of adolescents and/or young adults aged between 15 and 24 years, with a history of institutionalized care; (5) discussion and/or evaluation of programs and/or services to facilitate the transition between foster care and adult life. Abstracts were independently analyzed by two researchers and disagreements were resolved by consensus, resulting in a total of 32 articles which met all inclusion criteria.

In the eligibility stage, 12 articles were excluded after full text reading for the following reasons: (a) discussion of exploratory studies rather than intervention programs; (b) interventions pertaining to the transition to adulthood in populations other than former foster youth; (c) intervention programs with objectives other than facilitating the transition to adulthood. As such, in the inclusion stage, data extraction and quali- 
Table 1

Study Characteristics

\begin{tabular}{|c|c|c|c|c|c|}
\hline Authors/year & Country & Objective & Study design & $N$ & Age \\
\hline $\begin{array}{l}\text { 1. Brown \& Wilderson } \\
\text { (2010) }\end{array}$ & USA & $\begin{array}{l}\text { To examine the differences } \\
\text { between two groups who } \\
\text { received an intervention }\end{array}$ & $\begin{array}{l}\text { Quantitative } \\
\text { longitudinal } \\
\text { (observational) }\end{array}$ & 291 & $\begin{array}{l}\text { Mean } \\
18.5\end{array}$ \\
\hline $\begin{array}{l}\text { 2. Dworsky \& Pérez } \\
\text { (2010) }\end{array}$ & USA & $\begin{array}{l}\text { To investigate program } \\
\text { implementation }\end{array}$ & $\begin{array}{l}\text { Quantitative } \\
\text { cross-sectional } \\
\text { (observational) }\end{array}$ & 98 & Mean 20 \\
\hline $\begin{array}{l}\text { 3. Frimpong Manso } \\
\text { (2012) }\end{array}$ & Ghana & $\begin{array}{l}\text { To examine and describe } \\
\text { the preparation for leaving } \\
\text { foster care in Ghana }\end{array}$ & $\begin{array}{l}\text { Qualitative cross- } \\
\text { sectional (case } \\
\text { study) }\end{array}$ & 27 & 23 to 40 \\
\hline $\begin{array}{l}\text { 4. Goyette, Maan- } \\
\text { Feder, Turcotte, \& } \\
\text { Grenier (2016) }\end{array}$ & Canada & $\begin{array}{l}\text { To examine two programs } \\
\text { which aimed to prepare } \\
\text { individuals for the transition }\end{array}$ & $\begin{array}{l}\text { Qualitative } \\
\text { cross-sectional } \\
\text { (observational) }\end{array}$ & 31 & 16 to 18 \\
\hline $\begin{array}{l}\text { 5. Greeson, Garcia, } \\
\text { Kim, \& Courtney } \\
(2014)\end{array}$ & USA & $\begin{array}{l}\text { To evaluate the effectiveness } \\
\text { of the program in increasing } \\
\text { social support }\end{array}$ & $\begin{array}{l}\text { Quantitative } \\
\text { longitudinal } \\
\text { (experimental) }\end{array}$ & 194 & $\begin{array}{l}\text { Mean } \\
16.8\end{array}$ \\
\hline $\begin{array}{l}\text { 6. Greeson, Garcia, } \\
\text { Kim, Thompson, \& } \\
\text { Courtney (2015) }\end{array}$ & USA & $\begin{array}{c}\text { To evaluate the effectiveness } \\
\text { of the Life Skills Training } \\
\text { Program }\end{array}$ & $\begin{array}{l}\text { Quantitative } \\
\text { longitudinal } \\
\text { (experimental) }\end{array}$ & 482 & 16 to 21 \\
\hline $\begin{array}{l}\text { 7. Holt \& Kirwan } \\
\text { (2012) }\end{array}$ & Ireland & $\begin{array}{l}\text { To examine the role } \\
\text { of keyworking in preparing } \\
\text { for the transition }\end{array}$ & $\begin{array}{l}\text { Qualitative } \\
\text { cross-sectional } \\
\text { (case study) }\end{array}$ & 4 & 21 to 24 \\
\hline $\begin{array}{l}\text { 8. Jones \& Lansdverk } \\
(2006)\end{array}$ & USA & $\begin{array}{l}\text { To describe a resideptial } \\
\text { support program for foster } \\
\text { youth }\end{array}$ & $\begin{array}{l}\text { Quantitative } \\
\text { longitudinal } \\
\text { (cohort study) }\end{array}$ & 206 & 12 to 18 \\
\hline 9. Kirk \& Day (2011) & USA & $\begin{array}{l}\text { To evaluate a summer camp } \\
\text { for foster youth }\end{array}$ & $\begin{array}{l}\text { Quantitative/ } \\
\text { qualitative } \\
\text { longitudinal } \\
\text { (observational) }\end{array}$ & 38 & 15 to 19 \\
\hline $\begin{array}{l}\text { 10. Lawler, Sayfan, } \\
\text { Goodman, Narr, \& } \\
\text { Cordon (2014) }\end{array}$ & USA & $\begin{array}{l}\text { To evaluate the Academy } \\
\text { program }\end{array}$ & $\begin{array}{l}\text { Quantitative } \\
\text { cross-sectional } \\
\text { (observational) }\end{array}$ & 478 & $\begin{array}{l}\text { Mean } \\
15.6\end{array}$ \\
\hline $\begin{array}{l}\text { 11. Maposa \& Louw- } \\
\text { Potgieter (2012) }\end{array}$ & South Africa & $\begin{array}{l}\text { To evaluate a development } \\
\text { program for foster youth }\end{array}$ & $\begin{array}{l}\text { Quantitative/ } \\
\text { qualitative } \\
\text { longitudinal } \\
\text { (observational) }\end{array}$ & 30 & 18 to 25 \\
\hline 12. Mendes (2011) & Australia & $\begin{array}{l}\text { To evaluate program } \\
\text { effectiveness }\end{array}$ & $\begin{array}{c}\text { Qualitative } \\
\text { longitudinal } \\
\text { (observational) }\end{array}$ & 19 & NA \\
\hline $\begin{array}{l}\text { 13. Naccarato \& Park } \\
(2009)\end{array}$ & USA & $\begin{array}{l}\text { To verify the association between } \\
\text { individual goals and participation } \\
\text { in the program }\end{array}$ & $\begin{array}{l}\text { Quantitative } \\
\text { cross-sectional } \\
\text { (observational) }\end{array}$ & 365 & $\begin{array}{l}\text { Mean } \\
17.8\end{array}$ \\
\hline $\begin{array}{l}\text { 14. Nesmith \& } \\
\text { Christophersen (2014) }\end{array}$ & USA & $\begin{array}{l}\text { To evaluate the utility and } \\
\text { effectiveness of a transition } \\
\text { support facility }\end{array}$ & $\begin{array}{l}\text { Quantitative } \\
\text { longitudinal } \\
\quad \text { (quasi- } \\
\text { experimental) }\end{array}$ & 88 & $\begin{array}{l}15.3 \\
\text { mean }\end{array}$ \\
\hline
\end{tabular}




\begin{tabular}{|c|c|c|c|c|c|}
\hline $\begin{array}{l}\text { 15. Nsonwu, Dennison, } \\
\text { \& Long }(2015)\end{array}$ & USA & $\begin{array}{l}\text { To describe the use of therapy } \\
\text { to facilitate the transition }\end{array}$ & $\begin{array}{l}\text { Qualitative } \\
\text { cross-sectional } \\
\text { (observational) }\end{array}$ & 10 & $\begin{array}{c}16 \\
\text { mean }\end{array}$ \\
\hline $\begin{array}{l}\text { 16. Osterling \& Hines } \\
(2006)\end{array}$ & USA & $\begin{array}{l}\text { To describe the experience } \\
\text { of foster youth in the } \\
\text { program }\end{array}$ & $\begin{array}{l}\text { Quantitative/ } \\
\text { qualitative } \\
\text { longitudinal } \\
\text { (observational) }\end{array}$ & 52 & $\begin{array}{c}16.3 \\
\text { mean }\end{array}$ \\
\hline $\begin{array}{l}\text { 17. Senteio, Marshall, } \\
\text { Ritzen, \& Grant } \\
(2009)\end{array}$ & USA & $\begin{array}{c}\text { To determine whether the program } \\
\text { provides the opportunity for a } \\
\text { stable life in adulthood }\end{array}$ & $\begin{array}{l}\text { Quantitative } \\
\text { longitudinal } \\
\text { (observational) }\end{array}$ & 24 & $\begin{array}{c}20.3 \\
\text { mean }\end{array}$ \\
\hline $\begin{array}{l}\text { 18. Sinkkonen } \\
\text { \& Kyttälä (2015) }\end{array}$ & Finland & $\begin{array}{l}\text { To investigate the experience } \\
\text { of foster youth in a transition } \\
\text { support program }\end{array}$ & $\begin{array}{l}\text { Quantitative } \\
\text { cross-sectional } \\
\text { (observational) }\end{array}$ & 39 & 17 to 26 \\
\hline $\begin{array}{l}\text { 19. Uzoebo, Kioko, } \\
\& \text { Jones (2008) }\end{array}$ & USA & $\begin{array}{l}\text { To examine the perceived } \\
\text { needs of young adults during } \\
\text { the transistion }\end{array}$ & $\begin{array}{l}\text { Quantitative/ } \\
\text { qualitative } \\
\text { longitudinal } \\
\text { (observational) }\end{array}$ & 89 & $\begin{array}{c}16 \\
\text { mean }\end{array}$ \\
\hline $\begin{array}{l}\text { 20. Watt, Norton, } \\
\& \text { Jones (2013) }\end{array}$ & USA & $\begin{array}{l}\text { To describe the theoretical } \\
\text { background and program } \\
\text { implementation }\end{array}$ & $\begin{array}{l}\text { Quantitative/ } \\
\text { qualitative } \\
\text { longitudinal } \\
\text { (case study) }\end{array}$ & 155 & ND \\
\hline
\end{tabular}

Note. $N=$ Number of participants $/ \mathrm{ND}=$ Not described in the article.

tative analysis were performed in a final sample of 20 articles.

\section{Results}

\section{Study Characteristics}

A total of 14 studies were performed in the United States, while the remaining articles discussed investigations conducted in South Africa, Australia, Canada, Finland, Ghana and Ireland, as shown in Table 1.

In order to achieve their objectives, researchers adopted designs ranging from quantitative and cross sectional $(2,10,13$ and 18) or longitudinal (1, 5, 6, 8, 14 and 17), mixedmethods cross-sectional $(11,16,19$ and 20) or longitudinal (9) to qualitative cross-sectional $(3,4,7,12$ and 15). Studies which evaluated participants multiple times included two, three or even four follow-up assessments. The length of time between the first and last assessment in longitudinal studies ranged from three months to five years.

Most articles described observational studies $(65 \%)$, while the remaining investigations were either cross-sectional, case studies or experimental and quasi-experimental. The latter two cases accounted for only $15 \%$ of studies, and involved the assessment of interventions through control group comparisons.

Although all interventions were directed at a similar population, the age of participants ranged from 12 to 40 years. The wide range in participant age is attributable to the fact that studies included either (a) only adolescents preparing to leave foster care; (b) participants who were both preparing to leave and those who had already left institutional care and (c) only young adults who had already left the foster system. The distribution of publication years indicated that studies were distributed in a nearly uniform fashion until 2013, with the years of 2014 to 2016 accounting for a slightly higher percentage of publications ( $40 \%$ of the total sample).

\section{Characteristics of Intervention Programs}

All interventions involved activities aimed at facilitating the transition process; however, they varied in terms of their focus and comprehensiveness, as can be seen in Table 2 . 
Table 2

Characteristics of Intervention Programs

\begin{tabular}{ccc}
\hline Program & Objective & Format
\end{tabular}

1. Larkin Street Youth Services

2. Campus Support Programmes

3. Youth homes from SOS children's village

Moving On

\section{Friendship Group}

5. The Outreach

6. Life Skill Training

7. Keyworking

8. Academy

9. Michigan Educational Opportunities for Youth

10. Academy

\section{The Mamelani Project}

St Luke's Anglicare Leaving

12. Care and After Care Support Service

13. Independent Living Program of Northern California

14. Creating Ongoing Relationships Effectively

15. Foster Care Chronicles

16. Advocates to Successful Transition to Independence

17. Transition Resource Action Center
To provide housing, training, work, as well as educational and health services

To increase educational goals and encourage continued education

To prepare residents for independent living

To provide opportunities for the expression of emotions pertaining to the transition to independent living

To contribute to the identification of dysfunctional relationships and the development of healthy relationships

To contribute to the development of a social support network

To contribute to the acquisition of independent life skills

$$
\text { ND }
$$

To provide a stable living environment and an educational program to prepare youth for emancipation

To encourage self-efficacy, the acquisition of independent life skills and development of a support network.

To provide a stable living environment and an educational program to prepare youth for emancipation

To prepare shelter youth to become independent, responsible citizens

To provide assistance in several areas associated with emancipation

To offer assistance in the transition to adulthood

To contribute to relationships with adult reference figures

To increase the likelihood of participation in higher education and facilitate the adaptation to university

To contribute to the acquisition of independent life skills

To encourage self-sufficiency
Housing program

Consultation and mentoring within universities

Housing program

Eight group sessions

Eight group sessions

Weekly meetings with mentors

Five-week course, classroom format

Systematic mentoring

Boarding house

Four-day camp

Boarding house

Courses, workshops and systematic support

Individualized planning based on the needs and characteristics of each adolescent

17-week course, classroom format

Workshop with a duration of 12 to 17 weeks

Weekly group therapy sessions for 6 to 8 months

Meetings with mentors before and after leaving institutional care

Supportive housing (three types, for individuals with different degrees of autonomy) 
18. Supportive Housing

19. VISIONS

20. Foster Care Alumni Educational Success
To foster independent living skills, selfcontrol and responsibility

To teach the basic skills needed for a productive adult life

To encourage the continuation of higher education and prevent dropout
Supportive housing

Supportive housing

Consultation and mentoring within university

Note. $\mathrm{ND}=$ Not described in the article.

Most programs addressed at least three general domains of emancipation (e.g. work; study; living situation; interpersonal relationships; daily life activities). Three studies discussed programs which focused on encouraging continued education $(2,15$, and 20). Although their main goal was to improve academic performance, these programs also contributed to other aspects of the transition, such as financial, social and emotional support.

The format of the interventions also varied widely among studies, with services being offered in one of three modalities: housing; shortterm interventions; and long-term interventions. The programs which offered housing involved institutions which provided both accommodation and services to prepare youth for emancipation $(3,8,10$ and 19), or supportive group housing for young adults transitioning between shelters and independent living (1, 17 and 18). The aim of supportive housing is to prevent homelessness, but also offer educational activities, health care and skills training, in addition to emotional and social support.

Short-term interventions included programs offered by institutions other than those where the adolescents lived, with predetermined content and duration. These included summer camps (9), courses and workshops (6,13 and 14) and group meetings or psychotherapy (4 and 15). The length of short-term interventions ranged from four days to eight months. These programs tended to adopt one of two methodological approaches. Some involved knowledge transmission without the active participation of the adolescents themselves (6 and 13), while others relied on participatory methodologies and practical or experiential activities, despite having a fixed format $(4,9,14$ and 15).
Long-term interventions were also offered by institutions other than those where participants were sheltered, but included the systematic follow-up of adolescents and/or young adults, with varying frequency and intensity. This category includes some of the programs offered by universities (2 and 20), especially those which sought to maximize the opportunity for former foster youth to pursue higher education. The structure of these programs varied by institution, although all continued to monitor studies throughout their university years.

Long-term interventions with objectives reaching beyond academic performance $(5,7$, 11,12 and 16) involved the presence of mentors. The role of the mentor varied depending on the program, as did the individuals who took on this role, and the frequency and intensity of contact between the mentors and the adolescents. Nevertheless, across all programs, the main goal of mentoring was to facilitate the construction of a significant bond with an adult on whom the adolescents could count after leaving the shelter system.

\section{Assessment and Results of Intervention Programs}

The type of assessment performed by each study ranged from process evaluations, to assessments of the impact and effect of intervention programs. Articles which conducted process evaluations $(2,3,4,7,8,9,10,11,12,14,15$, $16,18,19$ and 20) did so in order to examine the execution of intervention programs, analyzing the procedures and resources used through interviews, observations, focus groups and ad hoc questionnaires, conducted during or after the intervention. This type of assessment often relied on the opinions of program participants and 
coordinators regarding intervention functioning and possible improvements in future editions.

Fifteen studies also assessed the effect of interventions at the end of the program by investigating changes in the desired direction. This was achieved using interviews; document reviews (records, institutional registries, etc.); psychometric scales; ad hoc questionnaires; and focus groups.

Two studies (5 and 6) used control group comparisons to evaluate the impact of an intervention on a given set of outcomes. The studies did not identify a significant association between the type of program offered and the analyzed outcomes over time. Therefore, these were among the few articles whose overall assessments were categorized as negative. Only one other program (13) received a negative assessment, after researchers found that participation in an independent living program was not associated with session goals and contents. Two of the programs which received a negative assessment (6 and 13) adopted an expositional approach, and identified the "classroom-like" structure of the intervention as a possible reason for their unsatisfactory findings.

As can be seen in Table 3, although $85 \%$ of studies obtained positive results, many acknowledged that modifications to the programs may have resulted in even more beneficial outcomes. Nevertheless, studies were also able to identify several strengths of each intervention.

The discussion of strengths and weaknesses (areas of improvement) shared some commonalities across studies. The first pertains to the importance of integrating participants in the community and adapting the program to its sociocultural context in order to maximize the likelihood of positive results. Another shared point of concern was the need to use participative methods and align the program with the interests and needs of participants. Many authors used the term "empowerment" to highlight the fact that adolescents and adults should be encouraged to make their own decisions and develop autonomy.

Though most intervention programs focused mainly on autonomy, several studies $(2,3,7,10$, $14,15,16$, and 18) also discussed the importance of bonding with adult attachment figures as an important contributor to positive outcomes. Be it as a main strength of the program, or a suggestion for improvement in future editions, social support and stable relationships had a central role in the results described by authors.

The last issue to be discussed by multiple studies is the apparent paradox between the need to invest in the assessment of intervention programs, and the difficulties in actually carrying this out. According to the authors, the obstacles to assessment included scarcity of resources and personnel, difficulty accessing participants, and ethical concerns.

\section{Discussion}

The present findings lay the groundwork for interesting reflections, both about the programs and their contributions to future research and interventions, but also about the different types of assessment conducted and the importance of these processes for the advancement of knowledge in the area.

Most programs chose to focus their efforts on education and preparation for the job market, as well as basic independent living skills (finding a place to live, shopping, financial management, paying bills, orienting oneself and using different means of transportation, cooking, etc.). These choices may reflect the findings of a series of investigations and policies developed in the 1990 s and early 2000s, with a focus on independent life skills training (Mallon, 1998; McMillen, Rideout, Fisher, \& Tucker, 1997). There is no question in the literature regarding the importance of preparing former shelter youth for independent living and occupational functioning. However, as suggested by the present findings and those of other recent exploratory studies, intervention programs which seek to prepare foster youth for adulthood must also focus on additional domains.

Studies involving Brazilian adolescents and young adults transitioning to independent living have found them to be unprepared to handle daily activities (Martinez \& Soares-Silva, 2008), but also identified several areas of concern such 
Table 3

Evaluation of Intervention Programs

\begin{tabular}{|c|c|c|c|c|c|c|}
\hline \multirow{2}{*}{ Program } & \multicolumn{3}{|c|}{ Program assessment } & \multicolumn{3}{|c|}{ Results } \\
\hline & Type & Instrument & Analysis & Total & Strengths & Areas of Improvement \\
\hline $\begin{array}{l}\text { 1. Larkin Street Youth } \\
\text { Services }\end{array}$ & Ef & $\mathrm{I}, \mathrm{D}$ & Descriptive & + & $\begin{array}{l}\text { Transition } \\
\text { planning }\end{array}$ & Referral to the program \\
\hline $\begin{array}{l}\text { 2. Campus Support } \\
\text { Programmes }\end{array}$ & Po & $\mathrm{I}, \mathrm{QA}$ & $\begin{array}{l}\text { Descriptive/ } \\
\text { Thematic }\end{array}$ & + & Social support & $\begin{array}{l}\text { Participant selection } \\
\text { and financial support }\end{array}$ \\
\hline $\begin{array}{l}\text { 3. Youth homes from } \\
\text { SOS children's village }\end{array}$ & Po & I, D, O & Thematic & ND & Stability of care & $\begin{array}{l}\text { Cultural factors and } \\
\text { living arrangements } \\
\text { after leaving shelter }\end{array}$ \\
\hline $\begin{array}{l}\text { 4. Moving On/ } \\
\text { Friendship Group }\end{array}$ & Po, Ef & I & Thematic & + & $\begin{array}{c}\text { New intervention } \\
\text { paradigm }\end{array}$ & ND \\
\hline 5. The Outreach & Ef, Im & QA & $\begin{array}{l}\text { Multilevel } \\
\text { Modeling }\end{array}$ & - & ND & $\begin{array}{l}\text { Professional } \\
\text { qualification }\end{array}$ \\
\hline 6. Life Skill Training & Ef, Im & QA & $\begin{array}{l}\text { Multilevel } \\
\text { Modeling }\end{array}$ & - & ND & Method (expositional) \\
\hline 7. Keyworking & Po & FG, I & Thematic & + & $\begin{array}{l}\text { Support after } \\
\text { leaving shelter }\end{array}$ & Mentor qualification \\
\hline 8. Academy & Po, Ef & VS, D, QA & $\begin{array}{l}\text { Descriptive/ } \\
\text { T-test }\end{array}$ & + & Stability of care & $\begin{array}{c}\text { Social and community } \\
\text { insertion }\end{array}$ \\
\hline $\begin{array}{l}\text { 9. Michigan } \\
\text { Educational } \\
\text { Opportunities for Youth }\end{array}$ & Po, Ef & $\mathrm{I}, \mathrm{FG}, \mathrm{QA}$ & $\begin{array}{l}\text { Descriptive/ } \\
\text { Thematic }\end{array}$ & + & $\begin{array}{l}\text { Method and } \\
\text { mentors }\end{array}$ & $\begin{array}{l}\text { Interaction with other } \\
\text { programs }\end{array}$ \\
\hline 10. Academy & Po, Ef & $\mathrm{D}, \mathrm{I}, \mathrm{QA}$ & $\begin{array}{l}\text { Correlation/ } \\
\text { Multiple } \\
\text { Regression }\end{array}$ & + & $\begin{array}{l}\text { Stable } \\
\text { relationships } \\
\text { with adults }\end{array}$ & ND \\
\hline $\begin{array}{l}\text { 11. The Mamelani } \\
\text { Project }\end{array}$ & Po, Ef & $\mathrm{D}, \mathrm{I}, \mathrm{VS}$ & Systematic & + & $\begin{array}{l}\text { Affective } \\
\text { relationships, } \\
\text { lower risk }\end{array}$ & $\begin{array}{l}\text { Living arrangements } \\
\text { after shelter, academic } \\
\text { performance }\end{array}$ \\
\hline $\begin{array}{l}\text { 12. St Luke's Anglicare } \\
\text { Leaving Care and After } \\
\text { Care Support Service }\end{array}$ & Po & $\mathrm{I}, \mathrm{FG}$ & Thematic & + & $\begin{array}{l}\text { Employability } \\
\text { and relationship } \\
\text { with mentors }\end{array}$ & $\begin{array}{l}\text { Use of community } \\
\text { resources }\end{array}$ \\
\hline $\begin{array}{l}\text { 13. Independent Living } \\
\text { Program }\end{array}$ & Ef & $\mathrm{D}, \mathrm{QA}$ & $\begin{array}{l}\text { Logistic } \\
\text { Regression }\end{array}$ & + & ND & Method \\
\hline $\begin{array}{l}\text { 14. Creating Ongoing } \\
\text { Relationships } \\
\text { Effectively }\end{array}$ & Po, Ef & $\begin{array}{l}\mathrm{T} 1(\mathrm{D}, \mathrm{QA}) \\
\mathrm{T} 2(\mathrm{QA}, \mathrm{I})\end{array}$ & $\begin{array}{l}\text { T-test/ } \\
\text { Thematic }\end{array}$ & + & $\begin{array}{l}\text { Method, mentor } \\
\text { qualification, } \\
\text { social support }\end{array}$ & ND \\
\hline $\begin{array}{l}\text { 15. Foster Care } \\
\text { Chronicles }\end{array}$ & Po, Ef & FG & Narrative & + & $\begin{array}{l}\text { Participatory } \\
\text { method }\end{array}$ & ND \\
\hline $\begin{array}{l}\text { 16. Advocates to } \\
\text { Successful Transition to } \\
\text { Independence }\end{array}$ & Po, Ef & $\mathrm{I}, \mathrm{FG}, \mathrm{QA}$ & $\begin{array}{l}\text { Descriptive/ } \\
\text { Thematic }\end{array}$ & + & $\begin{array}{l}\text { Significant } \\
\text { relationship } \\
\text { with mentors }\end{array}$ & $\begin{array}{l}\text { Interaction with other } \\
\text { programs, mentors }\end{array}$ \\
\hline $\begin{array}{l}\text { 17. Transition Resource } \\
\text { Action Center }\end{array}$ & Ef & QA & Chi-square & + & Employability & $\begin{array}{l}\text { Education/interaction } \\
\text { with community }\end{array}$ \\
\hline
\end{tabular}




\begin{tabular}{|c|c|c|c|c|c|c|}
\hline 18. Supportive Housing & Po & QA & $\begin{array}{c}\text { Descriptive/ } \\
\text { T-test }\end{array}$ & + & Social support & $\begin{array}{c}\text { Financial management, } \\
\text { employment, health }\end{array}$ \\
\hline 19. VISIONS & Po, Ef & VS, FG & ND & + & $\begin{array}{l}\text { Participatory } \\
\text { method }\end{array}$ & $\begin{array}{c}\text { Challenges of } \\
\text { independent living }\end{array}$ \\
\hline $\begin{array}{l}\text { 20. Foster Care Alumni } \\
\text { Educational Success }\end{array}$ & Po, Ef & $\begin{array}{l}\mathrm{I}, \mathrm{O}, \mathrm{QA} \\
\text { FG, D }\end{array}$ & $\begin{array}{l}\text { Descriptive/ } \\
\text { Thematic }\end{array}$ & + & $\begin{array}{l}\text { Participatory } \\
\text { method }\end{array}$ & Academic performance \\
\hline
\end{tabular}

Note. Ef=Effect / Im=Impact / Po=Process / FC=Focus Group / I=Interview / VS=Validated Scale/ QA=Questionnaire or Ad Hoc Scale $/ \mathrm{O}=$ Observation $/ \mathrm{D}=$ Documents $/ \mathrm{ND}=$ Not described in the article.

as the ambiguity of wishing for freedom while being afraid to leave the institution (Medrado, 2010); stigma in society (Costa, 2012; Medrado, 2010); and the adolescents' individual needs (Martinez \& Soares-Silva, 2008). These issues were also highlighted by participants in the studies reviewed. Many of the strengths and suggestions for improvement in the intervention programs pertained to the inclusion of additional goals for the interventions to help participants overcome difficulties beyond those associated with the practical aspects of daily living. Some of the factors identified by participants as essential to ensure a healthy transition process were relationships with adult reference figures, support networks, socioemotional support and satisfactory relationships with educators or institutional caretakers.

Some of the programs analyzed, such as the Foster Care Chronicles (Nsonwu et al., 2015), Moving On and the Friendship Group (Goyette et al., 2016), had already elected to focus on social and emotional issues. The idea that the transition to adult life is influenced by a series of factors beyond individual responsibility prompted these programs to focus their interventions on the expression of emotions associated with leaving foster care and the construction of healthy relationships (Goyette et al., 2016). Programs such as The Outreach (Greeson et al., 2014) and Keyworking (Holt \& Kirwan, 2012), on the other hand, turned to mentoring as a method of helping youth develop a social support network, while also providing life skills training. Mentoring programs have proved to be an effective strategy for promoting resilience and helping youth traverse the arduous journey faced by those with a history of institutional care (Greeson, 2013).
In addition to the content of the interventions, the method of delivery was found to exert a major influence on program success. Two important points must be highlighted in relation to this issue: (1) interventions must promote the active participation of adolescents and youth, (2) the format of the intervention must be adapted to the context and necessities of participants. These two concepts are interrelated: in the context of psychosocial interventions, active participation ensures the respect of individual and contextual differences among participants (Montero, 2004). Programs will be effective as long as they consider adolescents and young adults to be capable of making their own decisions, encouraging a sense of empowerment (Horochovski \& Meirelles, 2007).

In this systematic review, the sample consisted exclusively of international articles, which may speak to the scarcity of literature on the subject in Brazil. Nevertheless, national public policies pertaining to institutional care appear to be in line with the present findings, supporting many of the factors identified in this review as positive contributors to autonomy. This can be illustrated by legislation such as the Statute of Children and Adolescents (Estatuto da Criança e do Adolescente - ECA; Lei n. 8.069, 1990), the National Plan for Family and Community Living (Plano Nacional de Convivência Familiar e Comunitária - PNCFC; Conselho Nacional dos Direitos da Criança e do Adolescente [CONANDA], Conselho Nacional de Assistência Social [CNAS], Secretaria Especial dos Direitos Humanos [SEDH], \& Ministério do Desenvolvimento Social e Combate à Fome [MDS], 2006) and the Technical Recommendations for the Institutional Care of Children and 
Adolescents (CONANDA \& CNAS, 2009). The main goal of the PNCFC is to change the model of care applied to children and adolescents. Its guidelines include "strengthening the autonomy of children, adolescents and young adults as they construct their life projects" (CONANDA et al., 2006, p. 71), through a participative methodology which encourages shelter youth to take a leading role in their own development. The technical recommendations for institutional care, on the other hand, introduce the concept of group homes as a form of supported living for those leaving the shelter system. These arrangements consist of intermediate steps in the construction of autonomy, by allowing for self-determination, while also offering support and opportunities for the development of solutions and life projects (CONANDA \& CNAS, 2009).

However, in practical terms, these policies do not appear to have been implemented. Group homes are not available in many Brazilian states: in 2014, only 39 officially registered institutions catered specifically to youth, with most (26 units) located in southeastern Brazil (MDS, 2015). There is also a long way to go in terms of the changes required in the model of care available for shelter youth. Many of the goals set for the PNCFC in 2015 were directly related to the development of autonomy among adolescents and young adults, enlisting the support of several sectors of civil society in the process. However, recent studies highlight the unpreparedness of Brazilian youth as they leave institutional care, as well as the lack of living arrangements, education and occupational prospects for these individuals (Martinez \& SoaresSilva, 2008; Moreira, 2013; Romanelli, 2013; Rosa et al., 2012).

One way to ensure the effective implementation of public programs and policies is through continuous evaluation. The assessment of program outcomes and repercussions could then be used as a basis for decisions regarding the continuity of interventions (Cohen \& Franco, 1993). The studies analyzed in this review evaluated the process, effects and impact of several interventions. A complete assessment process should include all three of these items, starting with pro- cess evaluation, to ensure all activities are taking place as expected and in accordance with the initial planning. Effect assessment determines whether, and to what extent, the desired changes were observed. Lastly, impact assessment helps to verify whether the changes identified can be attributed to the intervention itself (Blasco \& Casado, 2009; Cohen \& Franco, 1993).

No consensus has yet been reached regarding the way these assessments should be conducted, or the design, method and techniques to be used at every stage. The confusion generated by this lack of standardization can be observed in some of the studies analyzed in this review, which claimed to have performed impact assessments, while their outcomes corresponded to evaluations of the effect of different interventions. Only two of the studies reviewed conducted impact assessments, comparing two groups of shelter youth, only one of whom participated in a given intervention. The studies found that the changes identified were not attributable to participation in the program, which underscores the importance of this type of procedure for goal assessment and program redesign. Another important issue pertaining to the assessment of intervention programs was the presence of numerous difficulties and obstacles reported by researchers during the assessment process. According to Blasco and Casado (2009), some factors are especially difficult to measure since they refer to abstract constructs, as is the case of autonomy. The need to measure a phenomenon which is by nature immeasurable presents a significant challenge, as researchers select the methods, instruments and measures that are most appropriate for the task at hand. In addition to these obstacles, researchers may have difficulty accessing participants, securing the financial resources to do so, and managing the ethical concerns that arise when studying populations with a history of vulnerability.

These obstacles have not prevented countries and institutions from evaluating their interventions for former shelter youth. However, most results are presented in the form of reports and local publications, which are not always available in electronic form. This explains the absence of articles pertaining to well-known 
programs such as Grupo Nós (Brazil) and Punt de Referéncia (Spain) in the present review. The lack of information on the outcomes of these and other programs in indexed journals may compromise the scientific advancement of institutional care, creating a gap between the professionals who work in the area and the researchers who study it.

According to Piccinini (1996) there should be constant interaction between research and practice, and neither can progress without the other. On the one hand, evaluation procedures are crucial for the comprehension of phenomena and the effective development of future programs and interventions (Ajuntament de Barcelona, 2017). On the other, services for former shelter youth, and the professionals who deliver them, are in a privileged position to help overcome the difficulties and challenges associated with conducting research in the area (Fernández, 2003). The distance between research and practice must be bridged, to allow for more comprehensive publications on which to base progressively more efficient interventions in the context of institutional care.

\section{Conclusion}

This systematic review identified some factors as crucial for the efficacy of programs to assist in the transition from shelters to adult life. Firstly, the format of the interventions must respect individual and contextual differences between participants. Longer-term programs which assist participants both before and after leaving institutional care received the highest approval ratings and had the most perceptible and persistent effects. The content of interventions must include both independent life skills training, as well as socioemotional support and community insertion. Lastly, program efficacy was found to be influenced by the method of delivery, with participatory methods, in which adolescents take a leading role in decision making, resulting in more positive outcomes.

One limitation of the present study is the fact that its sample was limited to scientific articles. Many of the programs reviewed publish their findings in reports, official documents, or even theses, dissertations and books. This may limit the present findings, though it does not diminish their relevance. There is a need to increase scientific productivity in the area. This is especially true for Brazil, where there is an urgent need for studies of this population on which to base interventions to promote quality of life and resilience. Professionals involved in this type of intervention are encouraged to evaluate their outcomes and publish their results. On the other hand, the scientific literature is encouraged to provide more opportunities for publications on the subject.

\section{Authors' Contributions}

Substantial contribution in the concept and design of the study: Luciana Cassarino-Perez; Jorge Castellá Sarriera e Carme Montserrat.

Contribution to data collection: Luciana Cassarino-Perez e Vitória Ermel Córdova.

Contribution to data analysis and interpretation: Luciana Cassarino-Perez; Jorge Castellá Sarriera e Carme Montserrat.

Contribution to manuscript preparation: $\mathrm{Lu}-$ ciana Cassarino-Perez e Vitória Ermel Córdova.

Contribution to critical revision, adding intelectual content: Jorge Castellá Sarriera e Carme Montserrat.

\section{Conflicts of interest}

The authors declare that they have no conflict of interest related to the publication of this manuscript.

\section{References}

Ajuntament de Barcelona. (2017). El perquè d'una recerca aplicada. In C. Montserrat \& F. Casas, Les Intervencions psicosocioeducatives em families amb infant sem riscen el marc dels Serveis Socials Bàsics (pp. 13-17). Barcelona, Spain: Author.

Blanco, A., \& Valera, S. (2007). Los fundamentos de la intervención psicosocial. Intervenciónpsicosocial, 3-44.

Blasco, J., \& Casado, D. (2009). Guiapràctica 5 Avaluaciód'impacte. Barcelona, Spain: Ivàlua. 
*Brown, S., \& Wilderson, D. (2010). Homelessness prevention for former foster youth: Utilization of transitional housing programs. Children and Youth Services Review, 32(10), 1464-1472. doi: 10.1016/j.childyouth.2010.07.002

Cohen, E., \& Franco, R. (1993). Avaliação de Projetos Sociais. Petrópolis, RJ: Vozes.

Costa, A. C. P. (2012). Trajetórias sociais de jovens que vivenciaram o processo de desligamento por maioridade em abrigos institucionais (Master thesis, Universidade Federal do Mato Grosso do Sul, Pantanal, MTS, Brazil).

Conselho Nacional dos Direitos da Criança e do Adolescente, Conselho Nacional de Assistência Social, Secretaria Especial dos Direitos Humanos, \& Ministério do Desenvolvimento Social e Combate à Fome. (2006). Plano Nacional de Promoção, Proteção e Defesa do Direito de Crianças e Adolescentes à Convivência Familiar e Comunitária. Retrieved from http://www. conselhodacrianca.al.gov.br/sala-de-imprensa/ publicacoes/PNCFC\%20_\%2028_12_06\%20 _\%20Documento\%20Oficial\%20_2_.pdf/view

Conselho Nacional dos Direitos da Criança e do Adolescente, \& Conselho Nacional de Assistência Social. (2009). Orientações técnicas para os serviços de acolhimento para crianças e adolescentes. Brasília, DF. Retrieved from http:// www.mds.gov.br/cnas/noticias/orientacoes_tecnicas_final.pdf

Del Valle, J. F., Bravo, A., Alvarez, E., \& Fernanz, A. (2008). Adult self-sufficiency and social adjustment in care leavers from children's homes: A long term assessment. Child \& Family Social Work, 13(1), 12-22. doi: 10.1111/j.13652206.2007.00510.x

Dworsky, A., Napolitano, L., \& Courtney, M. (2013). Homelessness during the transition from foster care to adulthood. American Journal of Public Health, 103(Suppl. 2), S318-S323. doi: 10.2105/ AJPH.2013.301455

*Dworsky, A., \& Pérez, A. (2010). Helping former foster youth graduate from college through campus support programs. Children and Youth Services Review, 32(2), 255-263. doi: 10.1016/j. childyouth.2009.09.004

European Union. (2014). Testing Social Policy Innovation: Primer for the training. Retrieved from ec.europa.eu/social/BlobServlet?docId=11919 \&langId $=$ en
Federación de Entidades con Proyectos y Pisos Asistidos. (2014). Jovenes ex-tutelados: el reto de emancipar-se hoy (Dossiers del Tercero Sector, núm. 33). Retrieved from http://www. tercersector.cat/sites/default/files/dossier jovenes_extutelados._el_reto_de_emanciparse_ hoy.pdf

Fernández, F., I (2003). ¿Investigación en atención primaria? Atención.Primaria, 31, 281-284.

*Frimpong Manso, K. A. (2012). Preparation for young people leaving care: The case of SOS Children's Village, Ghana. Child Care in Practice, 18(4), 341-356.

Greeson, J. K. (2013). Foster youth and the transition to adulthood: The theoretical and conceptual basis for natural mentoring. Emerging Adulthood, 1(1), 40-51.

*Greeson, J. K. P., Garcia, A. R., Kim, M., \& Courtney, M. E. (2014). Foster youth and social support: The first RCT of independent living services. Research on Social Work Practice, 25(3), 349-357. doi: 10.1177/1049731514534900

*Greeson, J. K. P., Garcia, A. R., Kim, M., Thompson, A. E., \& Courtney, M. E. (2015). Development \& maintenance of social support among aged out foster youth who received independent living services: Results from the Multi-Site Evaluation of Foster Youth Programs. Children and Youth Services Review, 53, 1-9.

*Goyette, M., Maan-Feder, V., Turcotte, D., \& Grenier, S. (2016). Youth empowerment and engagement: An analysis of support practices in the youth protection system in Quebec. Revista Espanola de Pedagogia, 74(263), 31-49.

*Holt, S., \& Kirwan, G. (2012). The "key" to successful transitions for young people leaving residential child care: The role of the keyworker. ChildCare in Practice, 18(4), 371-392.

Horochovski, R. R., \& Meirelles, G. (2007). Problematizando o conceito de empoderamento. Seminário Nacional Movimentos Sociais, Participação e Democracia, 2, 485-506.

Hudson, A. L., \& Nandy, K. (2012). Comparisons of substance abuse, high-risk sexual behavior and depressive symptoms among homeless youth with and without a history of foster care placement. Contemporary Nurse, 42(2), 178-186. doi: 10.5172/conu.2012.42.2.17

*Jones, L., \& Lansdverk, J. (2006). Residential education: Examining a new approach for improv- 
ing outcomes for foster youth. Children and Youth Services Review, 28(10), 1152-1168. doi: 10.1016/j.childyouth.2005.10.015

*Kirk, R., \& Day, A. (2011). Increasing college access for youth aging out of foster care: Evaluation of a summer camp program for foster youth transitioning from high school to college. Children and Youth Services Review, 33(7), 11731180. doi: 10.1016/j.childyouth.2011.02.018

*Lawler, M., Sayfan, L., Goodman, G., Narr, R., \& Cordon, I. (2014). Comprehensive residential education: A promising model for emerging adults in foster care. Children and Youth Services Review, 38, 10-19. doi: 10.1016/j.childyouth.2014.01.003

Lei n. 8.069, de 13 de julho de 1990. (1990). Dispõe sobre o Estatuto da Criança e do Adolescente e dá outras providências. Retrieved from http://www.planalto.gov.br/ccivil_03/leis/ L8069Compilado.htm

Liberati, A., Altman, D. G., Tetzlaff, J., Mulrow, C. Gøtzsche, P. C., Ioannidis, J. P. A., \& Moher, D. (2009). The PRISMA statement for reporting systematic reviews and meta-analyses of studies that evaluate healthcare interventions: Explanation and elaboration. Journal of Clinical Epidemiology, 62(10), 1-34. doi: 10.1136/bmj.b2700

Mallon, G. P. (1998). After care, then where? Outcomes of an independent living program. Child Welfare, 77(1), 61.

Martinez, A. L. M., \& Soares-Silva, A. P. (2008). O momento da saída do abrigo por causa da maioridade: A voz dos adolescentes. Psicologia em Revista, 14(2), 113-132.

*Maposa, J. F., \& Louw-Potgieter, J. (2012). An outcome evaluation of a Youth Development Programme. Social Work/MaatskaplikeWerk, 48(2). doi: 10.15270/48-2-97

McMillen, J. C., Rideout, G., Fisher, R., \& Tucker, J. (1997). Independent-living services: The views of former foster youth. Families in Society: The Journal of Contemporary Social Services, 78(5), 471-479.

Ministério de Desenvolvimento Social e Combate à Fome. (2015). Censo SUAS 2014. Brasília, DF.

Medrado, J. A. L. (2010). "Vou deixando a vida me levar...". Histórias de vínculos, rupturas e projetos de vida de jovens egressos de um abrigo em Salvador (Master thesis, Universidade Católica do Salvador, BA, Brazil).
*Mendes, P. (2011). Towards a community development support model for young people transitioning from state out-of-home care: A case study of St Luke's Anglicare in Victoria, Australia. Practice, 23(2), 69-81. doi: 10.1080/09503153.2011.557148

Mersky, J. P., \& Janczewski, C. (2013). Adult wellbeing of foster care alumni: Comparisons to other child welfare recipients and a non-child welfare sample in a high-risk, urban setting. Children and Youth Services Review, 35(3), 367-376. doi: 10.1016/j.childyouth.2012.11.016

Montero, M. (2004). La participación y el compromiso en el trabajo comunitario. In M. Montero, Introducción a la psicología comunitária: desarrollo, conceptos y procesos (pp. 225-254). Buenos Aires: Paidós

Montserrat, C., Casas, F., \& Sisteró, C. (2015). Estudio sobre la atención a los jóvenes extutelados: evolución, valoración y retos de futuro. Barcelona, Spain: Departament de Benestar Social i Família.

Moreira, I. M. (2013). Acolhimento institucional e qualificação profissional: Implicações da medida protetiva na vida do jovem egresso (Master thesis, Universidade Estadual do Ceará, Fortaleza, CE, Brazil).

*Naccarato, T., \& Park, K. (2009). Educational goal advancement of Foster Youth and the Independent Living Program. Journal of Public Child Welfare, 3(4), 372-390. doi: 10.1080/15548730903347846

National Council of the Public Ministry. (2013). Um olhar mais atento aos serviços de acolhimento de crianças e adolescentes no país: Relatório da resolução 71/2011. Brasília, DF. Retrieved from http://www.cnmp.gov.br/portal/images/stories/ Destaques/Publicacoes/Res_71_VOLUME_1_ WEB_.PDF

Nelson, G., \& Prilleltensky, I. (2005). Community psychology: Inpursuit of liberation and wellbeing. New York: Palgrave Macmillan.

*Nesmith, A., \& Christophersen, K. (2014). Smoothing the transition to adulthood: Creating ongoing supportive relationships among foster youth. Children and Youth Services Review, 37, 1-8.

*Nsonwu, M. B., Dennison, S., \& Long, J. (2015). Foster care chronicles: Use of the arts for teens aging out of the foster care system. Journal of 
Creativity in Mental Health, 10(1), 18-33. doi: 10.1080/15401383.2014.935546

Oshima, K. M. M., Narendorf, S. C., \& McMillen, J. C. (2013). Pregnancy risk among older youth transitioning out of foster care. Children and Youth Services Review, 35(10), 1760-1765. doi: 10.1016/j.childyouth.2013.08.001

*Osterling, K. L., \& Hines, A. M. (2006). Mentoring adolescent foster youth: Promoting resilience during developmental transitions. Child Family Social Work, 11(3), 242-253. doi: 10.1111/j.1365-2206.2006.00427.x

Piccinini, C. A. (1996). Sobre o relacionamento entre pesquisador e profissional em psicologia. Coletaneas da ANPEPP, 1, 31-40.

Rahamim, A., \& Mendes, P. (2016). Mental health supports and young people transitioning from out-of-home care in Victoria. Children Australia, 41(1), 59-68. doi: 10.1017/cha.2015.35

Romanelli, B. M. B. (2013). O que é feito dos jovens? Dimensões psicossociais e educativas no processo de acolhimento institucional (Doctoral dissertation, Universidade Federal do Paraná, Curitiba, PR, Brazil).

Rosa, E. M., Nascimento, C. R. R., Matos, J. R., \& Santos, J. R. dos. (2012). O processo de desligamento de adolescentes em acolhimento institucional. Estudos de Psicologia (Natal), 17(3), 361-368. doi: 10.1590/S1413-294X2012000300003

*Senteio, C., Marshall, K. J., Ritzen, E. K., \& Grant, J. (2009). Preventing homelessness: An examination of the transition resource action center. Journal of Prevention \& Intervention in the Community, 37(2), 100-111. doi: $10.1080 / 10852350902735601$
*Sinkkonen, H.-M., \& Kyttälä, M. (2015). Supportive housing in foster care: The views of young people. Child Care in Practice, 21(4), 408-424. doi: 10.1080/13575279.2015.1037251

Siqueira, A. C., \& Dell'Aglio, D. D. (2006). O impacto da institucionalização na infância e na adolescência: Uma revisão de literatura. Psicologia \& Sociedade, 18(1), 71-80. doi: 10.1590/S010271822006000100010

Stewart, C. J., Kum, H.-C., Barth, R. P., \& Duncan, D. F. (2014). Former foster youth: Employment outcomes up to age 30. Children and Youth Services Review, 36, 220-229. doi: 10.1016/j. childyouth.2013.11.024

*Uzoebo, V., Kioko, M., \& Jones, R. (2008). Deconstructing youth transition to adulthood services: Lessons learned from the VISIONS program. Vulnerable Children and Youth Studies, 3(1), 37-41. doi: 10.1080/17450120701767688

Yates, T. M., \& Grey, I. K. (2012). Adapting to aging out: Profiles of risk and resilience among emancipated foster youth. Development and Psychopathology, 24(2), 475-492. doi: 10.1017/ S0954579412000107

*Watt, T. T., Norton, C. L., \& Jones, C. (2013). Designing a campus support program for foster care alumni: Preliminary evidence for a strengths framework. Children and Youth Services Review, 35(9), 1408-1417. doi: 10.1016/j. childyouth.2013.06.002

Received: $25 / 04 / 2017$

$1^{\text {st }}$ revision: 06/05/2017

$2^{\text {nd }}$ revision: $1 \% 06 / 2017$

Accepted: 14/06/2017

(cc)BY (C) The Author(s), 2018. Open Access. This article is distributed under the terms of the Creative Commons Attribution 4.0 International License (http://creativecommons.org/licenses/by/4.0/), which permits unrestricted use, distribution, and reproduction in any medium, provided you give appropriate credit to the original author(s) and the source, provide a link to the Creative Commons license, and indicate if changes were made. 